\title{
Krzysztof Frysztacki*
}

\section{SOCJOLOGIA PROBLEMÓW SPOŁECZNYCH - RAZ JESZCZE}

Dlaczego „raz jeszcze”? Z dwóch splecionych z sobą, choć pozornie sprzecznych powodów. Po pierwsze podążamy śladami nadzwyczaj bogatej tradycji i współczesności badań oraz analiz socjologicznych. Tematyka ta, w złożonym wachlarzu ujęć konceptualnych, orientacji teoretycznych, uwarunkowań aksjologicznych, wreszcie tego, co zapewne najoczywistsze, składników empirycznych i aplikacyjnych, należy do kluczowych problemów socjologii. Jednocześnie kierujemy się prostym przekonaniem, że o socjologii problemów społecznych jest wciąż jeszcze bardzo wiele do powiedzenia, przede wszystkim ze względu na dynamikę zmieniających się i różnorodnych zjawisk społecznych, ale również w świetle tego, co socjologia problemów społecznych komunikuje w najnowszych ujęciach, do czego nas niejako „zmusza”. Charakterystyczny dla socjologii problemów społecznych jest obszar badawczy i praktyczny, w którym skupiają się zarówno specyficznie interpretowane ludzkie sprawy, jak i możliwe w związku z nimi działania.

Jeśli zaś mówimy o podstawach konceptualnych, to znaczy o problemowo zorientowanym interpretowaniu zagadnień społecznych, to możemy stwierdzić, że mamy dziś do czynienia z dominującym sposobem definiowania. Mianowicie w licznych studiach socjologicznych spotykamy się z takim rozumieniem problemów społecznych, które kładzie nacisk na powiązanie strony obiektywnej, realnych zjawisk i procesów oraz strony subiektywnej, kładącej nacisk na oddźwięk, jaki te zjawiska i procesy wywołują (oczywiście oddźwięk naznaczony myśleniem sceptycznym, negatywnym, przeciwstawiającym się danemu stanowi spraw). Problemy społeczne są zatem definiowane jako odstępstwa od oczekiwanych standardów (bądź wręcz jako ich złamanie), które budzą sprzeciw i ostatecznie skłaniają do przeciwdziałania. Problemy stają się częścią empirycznej rzeczywistości ze względu na fakt takiego właśnie ich postrzegania i konceptualizowania, istnieją, a badacze muszą być ich świadomi i za takowe je uznawać. Przejawiają one zatem cechy realności i są one wyznaczone obecnością w społecznej świadomości.

Tak zarysowana dwoistość została przedstawiona oraz zanalizowana w wielu korespondujących z sobą pracach, oczywiście z położeniem nacisku na nieco odmienne atrybuty i korelaty tego, co problemami społecznymi nazywamy. Zapewne najważniejszym przedstawicielem stanowiska relatywnie najwyraźniej zbliżonego do bieguna obiektywistycznego jest

\footnotetext{
* Uniwersytet Jagielloński; krzysztof.frysztacki@uj.edu.pl
} 
Robert Merton (1971). Gdy z kolei myślimy o biegunie subiektywistycznym, kluczowe ujęcie Malcolma Spectora i Johna Kitsuse (1987), poświęcone konstrukcji problemów społecznych, wyznaczyło bodajże najważniejszy, a w każdym razie najbardziej znamienny w socjologii nurt refleksji i analizy teoretycznej, a także empirycznej. Nie musimy podkreślać, że powyższe prace były następnie przedmiotem rozmaitych interpretacji. W tym miejscu tylko zauważmy ich wagę i miejsce w kontekście prowadzonych w tym zakresie prac, jak i ogólnie w socjologii problemów społecznych.

Podkreślić należy, że nie prowadzimy tutaj pogłębionej analizy rozwoju i cech tejże szczegółowej i zarazem szczególnej subdyscypliny socjologicznej; zainteresowany czytelnik znajdzie bogatą literaturę przedmiotu, rosnącą również ze względu na zaangażowanie wielu polskich autorów. Sam również wypowiedziałem się obszerniej na ten temat i nadal korzystam z własnego doświadczenia badawczo-publikacyjnego (Frysztacki 2009). Niemniej jednak, dążąc do zasygnalizowania zarówno podstaw, jak i stosunkowo najnowszych ustaleń socjologii problemów społecznych, warto przywołać trzy przykładowe, a zróżnicowane pod względem kierunków wypowiedzi studia, wybrane z obszaru zdecydowanie najbogatszej w tym zakresie literatury amerykańskiej.

Spójrzmy zatem na klasyczne rozumowanie przeprowadzone przez Earla Rubingtona oraz Martina Weinberga (2003). Zaproponowali oni tzw. socjologiczne perspektywy w postrzeganiu i wyjaśnianiu problemów społecznych, uogólnione sposoby interpretacji, będące zarówno pokłosiem myśli socjologicznej, jak i pozostające w związku z szerszym kontekstem warunków społecznych.

Za najstarszą z perspektyw uznano kategorię patologii społecznej, rozumianej jako swoista „choroba” społeczeństwa. Autorzy położyli nacisk na analizę przejawów owej „,choroby” doświadczanej przez społeczeństwo, któremu przypisali niejako naturalną misję realizowania pożądanego ładu i postępu. W kontekście tak rozumianej misji, owe skądinąd wywołujące sprzeciw „choroby” powinny skłaniać do zabiegów „leczniczych”, poczynając od edukacji moralnej, a na reformach instytucjonalnych kończąc. Kolejna perspektywa dezorganizacji społecznej oznaczała przeniesienie uwagi z konkretnych ludzi i sytuacji na ogólniejsze wzory i reguły oraz mechanizmy załamywania się tych ostatnich. Następnie w refleksji nad problemami społecznymi pojawił się kierunek dotyczący konfliktu wartości, znowu w powiązaniu z ogólniejszymi tendencjami zachodzącymi w naszej dyscyplinie, zwracającymi uwagę na sprzeczności wynikające ze zróżnicowanych wartości, a także ze splecionych z nimi interesów. Korelatem tego podejścia było i pozostaje założenie braku istnienia ,poprawnych”, obiektywnie słusznych reguł w sytuacji, gdy mamy do czynienia z ich zróżnicowaniem, swoistą społeczną konfrontacją między nimi. Takie rozumienie problemów społecznych prowadziło zaś do ukonstytuowania orientacji interpretacyjnych (przez autorów potraktowanych odrębnie, ale tutaj łączonych), wyznaczonych kategoriami zachowań dewiacyjnych i mechanizmów naznaczenia, charakteryzujących się przede wszystkim badaniem sposobów społecznego reagowania na domniemane (zdaniem niektórych) normatywne zakłócenia. Kolejna perspektywa krytyczna, mocniej zakorzeniona w makrostrukturalnie ujmowanych zjawiskach społeczno-politycznych, odwołuje się do dominującego zapewne założenia, że problemy społeczne, przynajmniej niektóre z nich, wywoływane są przez jednostronną przewagę sił rządzących. 
Wreszcie ostatnią z perspektyw jest konstruktywizm, ze wskazaniem na jego stronę aktywistyczną, na formułowanie społecznych żądań i pojawianie się związanych z tym aktywności oraz konfrontacji wynikającej z podejmowania tych działań przez odmiennie podmioty.

Jakie wnioski zatem można sformułować na podstawie powyższego przeglądu? Co najmniej dwa. Po pierwsze dzisiejsza socjologia problemów społecznych oferuje szerokie możliwości teoretyczne i rozmaite linie eksplanacyjne. Na pierwszy rzut oka jest to wachlarz podejść wręcz eklektyczny, ale jednocześnie, co warto podkreślić, uwzględniający wielorakość zjawisk problemowych w społeczeństwie, jak i próby interpretacji tych zjawisk. Spójrzmy również na kierunki ich wyodrębniania, znowu posługując się przykładem innej syntetyzującej w tym zakresie publikacji, również odnoszącej się do społeczeństwa amerykańskiego (Macionis 2010). Macionis, idąc w ślad za wcześniejszymi próbami tego rodzaju, ujął zjawiska problemowe reprezentatywne dla kontekstu amerykańskiego w postaci czterech typów, w ramach których znajduje się szesnaście konkretniejszych zjawisk (źródeł społecznych problemów). Wymienianie ich grozi schematyzmem, ale jednak dokonajmy tego zestawienia, dążąc do podkreślenia, że łącząc przejawy empiryczne z koncepcjami, możemy ogarnąć wręcz nieoczekiwanie bogaty zakres tego, co problemem się staje.

W zakresie nierówności społecznej autor wskazuje na problemy społeczne, takie jak:

- ubóstwo i bogactwo,

- nierówności rasowe i etniczne,

- nierówności o charakterze genderowym,

- nierówność związana ze starzeniem się.

W zakresie dewiacji, konformizmu i pomyślności życiowej znajdują się:

- przestępczość, przemoc, wymiar sprawiedliwości,

- seksualność,

- alkohol i narkotyki,

- zdrowie fizyczne i psychiczne.

W zakresie instytucji społecznych kwestie problemowe to:

- ekonomia i polityka,

- praca i miejsca zatrudnienia,

- życie rodzinne,

- edukacja,

- życie miejskie.

W zakresie problemów globalnych wymieniane są:

- globalna nierówność i populacja,

- technologia i środowisko,

- wojna i terroryzm.

W związku z tą analizą, w oryginale naturalnie obszerną i pełną szczegółów, nasuwa się nieco prowokacyjne pytanie, czy wszystko może stać się źródłem problemów społecznych? W najkrótszej odpowiedzi - tak, ze względu na, jak się zdaje, nieograniczony splot tego, od czego zaczęliśmy, współwystępujących czynników składających się na społeczną 
rzeczywistość i ocen tejże. Jednocześnie, stwierdzając niejako prowokacyjnie - nie, gdyż społeczne definiowanie danych zjawisk jako problemowych jest praktycznie zawsze ograniczone w swym zasięgu. Dla jednych dane problemy są właśnie takowymi, dla innych nie, a różnice te odzwierciedlają różnorodność, odmienność, przeciwieństwo przekonań, interesów, wizji człowieka i świata itd. Problemy społeczne uzyskują postać swoistej pojęciowej struktury, będącej następstwem przyjętej perspektywy definicyjnej. Znowu przywołajmy Mertona, który wskazuje na sędziów problemów społecznych (w tym również socjologów), na tych, którzy w danych okolicznościach mają więcej do powiedzenia lub są po prostu bardziej przekonujący.

Tymi okolicznościami są między innymi przestrzenne podstawy społecznego współżycia. Miejscowość i region, społeczności lokalne i regionalne - by przywołać najoczywistsze punkty odniesienia - są kontekstami procesów problemotwórczych oraz jednocześnie punktami odniesienia dla mechanizmów mających prowadzić do ich rozwiązywania. Community development, że wyjątkowo wykorzystamy określenie w języku angielskim, jest bodajże najlepiej znanym w tym względzie podejściem. Ważną perspektywę analityczną, odnoszącą się do powyższej kategorii, podejmuje kolejne studium (Leon-Guerrero 2011).

Community nie musi być bezpośrednio powiązana $\mathrm{z}$ wyodrębnionymi okolicznościami terytorialnymi; jej manifestacje mają również pozaprzestrzenny charakter. Tym niemniej zwróćmy uwagę na te przejawy i aspekty zarówno pojawiania się problemów, jak i prób sprostania im, które z przestrzenią są szczególnie splecione i ze względu na nią posiadają specyficzne właściwości (Leon-Guerrero 2011: 373-428).

Perspektywa community oznacza empiryczne umieszczenie danych (szeroko rozumianych) problemów, takoż ich narastania i przebiegu, wreszcie ewentualnego słabnięcia w sposób, w którym czynniki przestrzenno-fizyczne, a w konsekwencji społeczne, mają szczególne znaczenie. Ilustrację stanowią przykłady miast i tego, co się w nich i z nimi dzieje, począwszy od ich rozwoju, kompozycji i zmiany populacyjnej. Przykładowo urbanizacja i suburbanizacja mogą się wyrażać (wskaźniki znowu są zarówno obiektywne, jak i subiektywne) w przejawach równowagi i pozytywnego wpływu na jakość życia czy też odwrotnie, w przejawach zakłóceń o charakterze bądź komunikacyjnym, bądź zdolności do utrzymywania uchwytnej całości lub więzi pozwalających na współpracę. Tenże proces wzrostu (czy rozwoju) skorelowany jest z sytuacją na rynku mieszkaniowym, ze zróżnicowaną zdolnością jego uczestników do stwarzania satysfakcjonujących warunków mieszkaniowych, z ewentualnymi zakłóceniami (z ekstremalnym zjawiskiem bezdomności włącznie).

Rewaloryzacja przestrzeni miejskiej oznacza jej modernizację, materialne podniesienie jakości, ale jej gentryfikacyjny aspekt może owocować odepchnięciem niektórych dotychczasowych użytkowników i dekompozycją dotychczasowych stosunków społecznych, niekoniecznie korzystną, by ująć to bardzo ostrożnie. Poszczególne składniki materialnej bazy życia miejskiego - gospodarka wodna i zagospodarowanie śmieci, by znowu posłużyć się tylko wybranymi przykładami obecnymi w życiu każdego - wymagają mobilizacji zasobów, przy czym jej rezultaty mogą być społecznie różnicujące. Wreszcie współczesne miasta metropolitalne, a takie są obecnie decydującymi formami przestrzennymi, są jednocześnie czy to regionami miejskimi, ze skomplikowaną siatką wewnętrznych oddziaływań, czy co najmniej czynnikami wpływającymi na stan i perspektywy szerszej rzeczywistości regionalnej. 
Socjologia problemów społecznych - raz jeszcze

Analiza społecznych reakcji na trudną do ogarnięcia wielość tych zjawisk i zagadnień wymaga uwzględnienia pewnych zasadniczych właściwości. Przede wszystkim, kto reaguje? Jakie są zbiorowe podmioty określające pozytywne i negatywne strony funkcjonowania w warunkach będących ich udziałem? Które przejawy całościowego społecznego zorganizowania stają się decydującymi punktami odniesienia? Czy jest to społeczność całego miasta, czy raczej są to wyodrębnione zbiorowości, mające raczej cechy podspołeczności, bądź też odwrotnie, czy są to całości o większym, metropolitarnym oraz regionalnym wymiarze? Kto i jak może przeciwdziałać, gdy rozumienie danych spraw nabiera dominującego, problemowego charakteru? To znowu bogaty splot zagadnień, wśród których wyróżnijmy tylko - raz jeszcze po angielsku - community organizing w dążeniu do kolektywnego rozwiązywania problemów (Rubin i Rubin 2001), z uwzględnianiem nie jedynego, ale wśród innych kluczowego kontekstu lokalno-regionalnego.

Podstawą refleksji socjologii problemów społecznych o teoretyczno-aksjologicznej wymowie jest poszukiwanie sił społecznych, mających być narzędziem działania w kierunku poprawienia jakości życia, zarówno na rzecz jednostek, jak i społeczności, a organizowanie tychże społeczności ma być antidotum na bezsilność i niezdolność do wywołania pożądanej przez te społeczności zmiany. Za czynniki operacjonalizacji uważa się w przede wszystkim społeczną mobilizację oraz społeczną produkcję. Ta pierwsza skupiona jest wokół starań, by zbliżyć ludzi do siebie ze względu na wspólne cele, zachęcić ich do społecznej, a tym bardziej specyficznej politycznej aktywności, uzyskać efekt zbiorowej siły i płynących z tego możliwości. Ta druga kładzie nacisk na tworzenie społecznych służb i usług, zabezpieczanie możliwych dóbr materialnych, ewentualne zapewnianie własności. Nie są to mechanizmy, między którymi nie dochodziłoby do napięć, począwszy od pozornie nieistotnych, a w istocie mających swą znamienną wymowę różnic pojęciowych. I tak w przypadkach mobilizacji mówimy zwykle o kampaniach, co głównie oznacza dążenie do zmiany, nawet jeśli może wiązać się z tym swoista konfrontacja $\mathrm{z}$ istniejącym stanem rzeczy; jeśli chodzi o produkcję, to słowem kluczem są projekty, za którym kryje się raczej korzystne dostosowywanie się do istniejącej rzeczywistości. To zresztą nie jedyny dylemat. Nasuwa się ważne pytanie, czy możemy mówić o wyłącznie funkcjonalnym związku między środkami oraz celami, czy też pojawiają się (lub mogą pojawiać się) sprzeczności między nimi? Czy dyskutowana organizacja życia lokalnego jest po prostu instrumentalna, jest narzędziem działania czy też celem samym w sobie? Wymaga to dokładnych rozważań, teraz jednak pozostańmy przy tych skróconych uwagach, przyjmując jednocześnie, że community organizing i community development są przejawami grupowych, pomyślnych zmagań z wieloma problemami społecznymi. Ten wniosek, na podstawie bardzo bogatych doświadczeń empirycznych, możemy z pewnością postawić.

Nie trzeba podkreślać, że w artykule tylko dotykamy licznych zagadnień, sygnalizując je lub wskazując na potrzebę znacznie wnikliwszej analizy czy starając się wywołać dalsze pytania. To oczywiste. Powiedzmy jednak na koniec, że socjologia problemów społecznych służy rozpoznaniu empirycznemu i praktyce. Jeśli tak, zaznaczone powyżej atrybuty skorelowane z czynnikiem terytorialnym nie zostały wyróżnione bez dodatkowego powodu, wręcz przeciwnie. Czy - to ostatni wątek - ta ścieżka socjologiczna może również służyć Małopolsce? Pytanie jest retoryczne. Powiedzmy więc, że „nasz” region jest pod tym względem 
wielokierunkowym wyzwaniem. Jest immanentną częścią makrostrukturalnego i makroprocesualnego polskiego świata, a jednocześnie bytem samym w sobie, skłaniającym do pogłębionych badań, co zresztą jest już właściwością naszego środowiska badawczego (Bukowski 2011). Jest całkowicie uzasadnionym przedmiotem dalszych analiz, jak również prób przekuwania ich w rezultaty aplikacyjne.

\section{BIBLIOGRAFIA}

Bukowski, Andrzej. 2011. Region tradycyjny w unitarnym państwie w dobie globalizacji. Przypadek województwa małopolskiego, Kraków: Wydawnictwo Uniwersytetu Jagiellońskiego.

Frysztacki, Krzysztof. 2009. Socjologia problemów społecznych, Warszawa: Wydawnictwo Naukowe Scholar.

Leon-Guerrero, Anna. 2011. Social Problems: Community, Policy, and Social Action, Thousand Oaks: Pine Forge Press.

Macionis, John J. 2010. Social Problems, Upper Saddle River: Prentice Hall.

Merton, Robert K. 1971. Social Problems and Sociological Theory, w: Robert K. Merton i Robert Nisbet (red.), Contemporary Social Problems, New York: Harcourt Brace Jovanovich, s. 793-845.

Rubin, Herbert J. i Irene S. Rubin. 2001. Community Organizing and Development, Boston: Allyn and Bacon.

Rubington, Earl i Martin S. Weinberg. 2003. The Study of Social Problems: Seven Perspectives, New York: Oxford University Press.

Spector, Malcolm i John I. Kitsuse. 1987. Constructing Social Problems, New York: Aldine de Gruyter. 